\title{
Tutkimukseen perustuvan asiantuntija- tiedon käyttö päätöksenteossa: esimerkkinä sote-uudistus
}

\author{
Heikki Hiilamo
}

\begin{abstract}
Using scientific knowledge in decisionmaking: a case study of social and health care reform

Cabinets in Finland have tried to reform the administration of social and health-care services. Experts have played an important role in the preparation of the reform. By April 2019 all efforts, one after another, had failed. Since 2005 a great deal of time and money has been wasted with the end result that the sought-after reform has been delayed. This article focus on the role of academic experts in the preparation of the reform. The research question is how scientific knowledge was used in decision-making on the reform. The research material is derived from key working groups' reports which are examined by applying qualitative content analysis. The results demonstrate that the academic experts had hardly played any role at the start of the reform. When the experts were given more influence, however, they relied heavily on scientific authority as a method to justify their arguments, where the methods themselves remained in the background. In sum, a community of practice methods combining expertise from academia and practice could bring better solutions for the reform.
\end{abstract}

Key words: Social and health care reform, scientific experts' roles, communities of practice

\section{JOHDANTO}

Poliittisia päätöksiä halutaan yhä useammin perustella tutkitulla tiedolla, jonka tuottamisessa akateemisilla asiantuntijoilla on keskeinen rooli (esim. Ansell \& Geyer 2017; Hellström ym.
2019; Nieminen ym. 2019; Sorsa 2017; Ylönen ym. 2020). Baronin (2018) mukaan alun perin lääketieteessä harjoitettu tutkimukseen perustuva politiikka (evidence based-policy) on laajentunut 2000-luvulla kattavammin yhteiskuntapolitiikkaan. Baron (2018) liittää kehityksen hyvinvointivaltioiden kypsymiseen. Baronin "jymymenestyksiksi" kutsumat suuret uudistukset on jo tehty (Suomessa esim. peruskoulu, julkinen terveydenhuolto, työttömyysturva). Hyvinvointivaltioiden kehittäminen edellyttää sitä, että ehdotettuja uudistuksia verrataan nykyisiin käytäntöihin. Tutkimustiedon avulla on mahdollista selvittää, tuovatko uudistukset kustannustehokkaita parannuksia nykytilaan vai eivät. Tämän tutkimuksen tarkoituksena on analysoida tutkimukseen perustuvan asiantuntijatiedon käyttöä Suomen sosiaali- ja terveyspalveluiden uudistamisessa.

Tieteen ja politiikan välinen yhteys ei ole suoraviivainen (esim. Virtanen ym. 2015). Intressivapaata tietoa ei ole olemassa: kaikki käytettävissä oleva tietoa tulee väistämättä edustaneeksi aina joitain voimasuhteita ja joitain intressejä (Sorsa 2017). Tehokkuusvaatimusten ja ylikireiden aikataulujen leimaavat päätöksentekotilanteet rajoittavat julkishallinnon mahdollisuuksia käsitellä tietoa kokonaisvaltaisesti. Evidenssiperusteinen politiikka voikin muuttua politiikkaperusteiseksi evidenssin valikoinniksi, missä tutkimusnäyttöä tarkastellaan "kriittisen arvioinnin sijaan sen mukaan, mikä on päätöksenteon suhteen kulloinkin kätevintä, yksinkertaisinta ja parhaiten saatavilla olevaa" (Sorsa 2017; 76, ks. myös esim. Marmot 2004). Kiireen lisäksi muita esteitä ovat muun muassa se, ettei tiedon kysyntä ja tarjota aina kohtaa, yhteistä kieltä ei löydetä eikä asiantuntijarooleja tunnisteta. Ahonen (2015) paikallistaa tietoon perustuvan päätök- 
senteon ongelmat politiikan, virkamiestoiminnan ja tieteenharjoittamisen erilaisiin institutionaalisiin logiikkoihin, joissa poliittista logiikkaa kuvaa "deliberointi", virkamieslogiikkaa "rationaalisuus" ja tieteenharjoituksen logiikkaa "autonomia". Lisäksi tieteellinen tieto on vain yksi kilpaileva päätöksenteon peruste tai argumentti henkilökohtaisten kokemusten, mielipiteiden, puolueen näkemyksen ja äänestäjien kannan rinnalla (Lähteenmäki-Smith \& Kuitunen 2015).

Aikaisempi tutkimus kritisoi erityisesti ylhäältä alaspäin suuntautuvia malleja tutkimustiedon käytössä (Ansell \& Geyer 2017; Hellström ym. 2019). Niiden sijaan tutkijat pitävät tärkeänä pragmaattisuutta, dialogia ja sellaisten yhteistoimintamallien kehittämistä, jotka tekevät mahdolliseksi erilaisen asiantuntemuksen ja asiantuntijatiedon yhteensovittamisen valmisteluprosessissa. Tutkimustiedon uusia käyttötapoja on pohdittu ennen muuta ympäristöpolitiikassa, jossa joudutaan ratkaisemaan niin kutsuttuja viheliäisiä ongelmia (esim. Rose ym. 2017).

Tutkimustiedon käytön analyysissä on otettava huomioon, ettei tieto asetu itsestään osaksi päätöksentekoa. Tiedon välittämistä kuvataan muun muassa sanoilla tiedon levittäminen (disseminaatio), siirtäminen (transfer) sekä välitys (brokerage). Hukkisen (2016) mukaan tiedon välitys (knowledge brokerage) viittaa pyrkimyksiin saattaa tutkimustieto ja päätöksenteko toistensa saataville erilaisten tiedon jakamisten ja välittämisen mekanismien avulla. Michaels (2009) jakaa tiedon välityksen kuuteen eri vaihteeseen: tiedon käyttäjä kommunikoi tiedon tarpeesta, asiantuntijoiden etsiminen, asiantuntijoiden ja tiedon käyttäjien saattaminen yhteen, tiedon tarpeen välittäminen valituille asiantuntijoille, tiedon käyttäjien ja asiantuntijoiden yhteistyö tiedon välittämiseksi sekä asiantuntijoiden ja tiedon käyttäjien valmiuksien parantaminen tiedon välittämisessä. Asiantuntijoiden valitsemisella ja asiantuntijoiden toiminnalla on siis keskeinen rooli siitä, miten tutkimustieto välittyy päätöksentekoon.

Suomessa on pyritty kehittämään käytäntöjä tutkimustiedon hyödyntämiseksi päätöksenteossa (esim. Sorsa 2017). Niemisen ja kumppaneiden (2019) Valtioneuvoston kanslialle laatiman kirjallisuuskatsauksen mukaan poliittisen päätöksenteon mekanismit ja ohjaus ovat yhteydessä suoraan tutkimustiedon käytön tapoihin ja vai- kuttavuuteen. Lisäksi ne vaikuttavat rakenteisiin, joissa tutkimustietoa tuodaan päätöksenteon ja lainvalmistelun tueksi. Tutkimustiedon käyttöön luovat leimansa myös muun muassa hallinnon ja tutkimusorganisaatioiden väliset verkostot, vuorovaikutus ja viestintä. Nieminen ja kumppanit (2019) mainitsevat myös käytettävissä olevien henkilöstön ja asiantuntijoiden määrän tekijöinä, jotka vaikuttavat tutkimustiedon käyttöön lainvalmistelussa. Eri päätöksenteon vaiheissa - esimerkiksi työryhmissä ja valiokuntakuulemisissa - tutkimustieto välittyy akateemisten asiantuntijoiden kautta päätöksentekoon. Sorsa (2017) pitää käsitettä politiikkaperusteisesta evidenssistä naiivina, koska kaikki päätöksenteko perustuu jonkinlaiseen tiedon valikointiin. Päätöksentekijät eivät yleensä itse ehdi tai kykene arvioimaan kattavasti ja kriittisesti tutkimusnäyttöä. Tutkimustietoa välittävillä asiantuntijoilla onkin keskeinen rooli sen tiedon tuottamisessa, johon valikointi kohdistuu.

Suomen hallitukset ovat vuodesta 2005 alkaen yrittäneet uudistaa sosiaali- ja terveyspalveluiden hallintoa (Valli-Lintu 2017, 2019), jonka reformia on myös kuvattu viheliäiseksi tai pirulliseksi ongelmaksi (Erhola ym. 2019). Huhtikuuhun 2019 mennessä yritykset sote-uudistuksen toteuttamiseksi olivat kerta toisensa jälkeen päättyneet epäonnistumiseen. Valtava määrä valmistelutyötä oli mennyt hukkaan ja laajasti tarpeelliseksi tunnustettu uudistus oli viipynyt (Hiilamo 2020). Vuodesta 2005 asti vireillä ollut sote-uudistus tarkoittaa sosiaali- ja terveyspalveluiden hallinnon uudistamista. Kyseessä ei ole palveluiden sisällön uudistus. Uudistuksen jälkeenkin sote-järjestäjän on tarjottava asukkailleen "tarpeen mukaisia palveluita", mutta oikeutta saada palveluita ei ole täsmennetty lainsäädännössä muutamia poikkeuksia lukuun ottamatta. Tärkeimmät sosiaali- ja terveyspalveluiden sisältöä määrittävät lait ovat sosiaalihuoltolaki (1301/ 2014) ja terveydenhuoltolaki (1326/2010). Soteuudistus ei pyri yhdistämään lakeja eikä uudistamaan perusteellisesti niiden sisältöä. Sen sijaan uudistuksen kohteena on sosiaali- ja terveyspalveluiden järjestäminen, tuotanto ja rahoitus. Myöhemmin mukaan tuli myös valinnanvapauden lisääminen (Brommels 2016).

Lähtökohta uudistuksen toteuttamiselle on erittäin haasteellinen, koska hallinnon uudistaminen puuttuu muun muassa eri professioiden 
toimintaan sekä alueellisen vallan jakautumiseen Suomessa. Venäjän tsaari Aleksanteri II:n keisarillinen julistus vuonna 1869 määräsi, että kuntien tuli itse vastata kulkutautien ja eläinruttojen aiheuttamista kustannuksista (Keisarillisen majesteetin armollinen julistus.. 1869). Käytännössä julistus siirsi vastuun terveydenhuollosta valtiolta kunnille (Mattila 2011, 49). Vuoden 1865 kunnallishallintoasetus (1865) siirsi kirkkopitäjien vastuulla olleet maalliset asiat maalaiskuntien tehtäväksi (Keisarillisen majesteetin armollinen asetus.. 1865). Myöhemmin hyvinvointivaltiota luonut lainsäädäntö on luovuttanut vastuun kehittyneistä julkisista palveluista kunnille, kun taas valtio yhdessä sosiaaliturvarahastojen kanssa on vastannut tulonsiirroista. Kuntalain mukaan kunta hoitaa itsehallinnon nojalla itselleen ottamansa tehtävät ja järjestää sille laissa erikseen säädetyt tehtävät. Laissa säädettyihin tehtäviin kuuluu sosiaalija terveyspalveluiden järjestäminen. Sote-uudistuksen ydinkysymys on, kuka vastaa sote-palveluista - toisin sanoen mikä taho järjestää, rahoittaa ja/tai tuottaa sote-palvelut.

Sote-uudistuksen valmistelussa erityisesti Terveyden ja hyvinvoinnin laitoksen (THL) asiantuntijat (THL 2011, 2012) ovat tuoneet esille, että Suomen kuntien asukasluku ja voimavarat poikkeavat - historiallisista syistä - runsaasti toisistaan. Tämä on sote-järjestämisen ja rahoituksen ydinongelma. Kuntien perustuslaillinen asema on sama riippumatta siitä, onko niissä 94 vai 639226 asukasta (Sottunga vs. Helsinki keskiväkiluku 2017), joten pienimmätkin kunnat ovat vastuussa vaativien sote-tehtävien hoitamisesta siinä missä suuretkin kunnat. Suurten ikäluokkien aiheuttama väestön ikääntyminen kärjistää kuntien vaatimusten ja voimavarojen välistä ristiriitaa erityisesti 2020-luvulla. THL:n asiantuntijaryhmät $(2011,2012)$ ovat korostaneet sitä, että Suomi on sote-rahoituksen ja -järjestämisen kummallisuus kansainvälisessä vertailussa: missään muualla maailmassa ei näin laajoja tehtäviä ole näin eri kokoisten kuntien harteilla.

Terveyspalveluiden osalta vahva tutkimusnäyttö puoltaa isoja väestöpohjia. Riittävän väestöpohjan tasoa on tutkittu empiirisesti esimerkiksi kustannusten vaihtelun, palvelutarpeiden vaihtelun ja vertailevan tutkimuksen avulla
(Pekurinen ym. 2011). Pienimpien järjestäjien on mahdotonta ennakoida terveysmenojaan. Vaikeasti sairaan tai vammaisen lapsen syntymä, muutaman ihmisen vakava sairastuminen, epidemioista puhumattakaan, voi kerralla keikauttaa järjestäjän budjetin. Sosiaalipalveluiden osalta vastaava näyttö on heikompi tai olematon (Muuri 2016). Muissa Pohjoismaissa sosiaalipalvelut ovat kuntien vastuulla, mutta Ruotsissa ja Tanskassa kuntia on selvästi vähemmän ja ne ovat suurempia kuin Suomessa (Ruotsissa 290 kuntaa, Norjassa 428 kuntaa, Tanskassa 98 kuntaa ja Islannissa 74 kuntaa).

\section{Tutkimustehtävä}

Tässä tutkimuksessa lähestytään asiantuntijatiedon käyttöä sote-uudistusta koskevassa päätöksenteossa pragmatismin isänä tunnetun yhdysvaltaisen filosofin Charles S. Peircen (18381914) uskomusten perustelutapojen avulla. Tavoitteena on lisätä ymmärrystä tutkimustiedon roolista sote-uudistuksen valmistelussa. Juha Sipilän hallituksen aikana vuosina 2015-2019 sote-uudistuksen yhteydessä eduskunnan valiokunnissa kuultiin noin 1500 asiantuntijaa yliopistoista, valtion asiantuntijavirastoista, eri sidosryhmistä sekä maakunnista (Erhola ym. 2019). Tässä tutkimuksessa keskitytään pääasiassa ennen eduskuntakäsittelyä tapahtuneeseen valmisteluun ja akateemisten sote-asiantuntijoiden rooliin. Tutkimuskysymyksenä on se, miten sote-uudistuksessa on perusteltu uskomuksia ja erityisesti minkä roolin perustelutavat ovat antaneet akateemisille sote-asiantuntijoille vuosina 2005-2019.

Sovellan Peircen teoreettista jäsennystä soteuudistuksen vaiheita kuvaavaan aineistoon. Aluksi määrittelen sote-asiantuntijuuden. Poliittisessa prosessissa sote-uudistus on kytkeytynyt läheisesti paikallishallinnon (kuntarakenteen ja maakuntien) uudistamiseen (Valli-Lintu 2017). Rajaan tämän valmistelun tarkastelun ulkopuolelle ja keskityn yksinomaan sote-palveluiden uudistamiseen. Analyysiosuudessa tarkastelen perustelutapojen esiintymistä sote-valmistelun eri vaiheissa 2005-2019. Lopuksi esitän ratkaisuehdotuksen siitä, miten akateemista asiantuntijuutta voitaisiin paremmin käyttää sote-uudistuksen ja muiden vastaavien uudistusten apuna. 


\section{SOTE-ASIANTUNTIJAT}

Sote-uudistus on monien organisaatioiden samanaikainen muutos, jossa järjestelmien osat liittyvät toisiinsa ja vaikuttavat toisiinsa. Näin ollen verkostossa tapahtuvia dynaamisia muutoksia on mahdotonta ennustaa ja sote-uudistuksen vaikutuksia on vaikea arvioida. Uudistuksessa tarvittavaa tutkimustietoa on vaikea määritellä yksiselitteisesti. Tämä korostaa niiden asiantuntijoiden roolia, jotka välittävät tutkimustietoa.

Yleisellä tasolla asiantuntijuuteen kuuluu se, että asiantuntijamielipiteet voidaan hyväksyä julkisessa keskustelussa kyseenalaistamatta niiden oikeutusta (vrt. Peirce 1877). Asiantuntemus voi perustua esimeriksi opintoihin, tutkimukseen tai käytännön työssä hankittuun osaamiseen. Lisäksi on otettava huomioon, että jokaisella ryhmällä - esimerkiksi poliitikoilla, virkamiehillä, median edustajilla ja tiedeyhteisön jäsenillä - on oma tapansa määritellä asiantuntijuus. Julkisuudessa sote-asiantuntijuutta voidaan luoda kehäpäätelmällä: sote-asiantuntijoita ovat automaattisesti ne, joita media käyttää asiantuntijoina - riippumatta siitä, miten "päteviä" asiantuntijoita he ovat. Collinsin ja Evansin (2007) mukaan asiantuntijuus voidaan jakaa interaktionaaliseen asiantuntijuuteen ja kontribuutioasiantuntijuuteen, joissa molemmissa asiantuntijuus perustuu vuorovaikutukseen alan muiden toimijoiden kanssa. Kontribuutioasiantuntijuuteen kuuluu kuitenkin myös kyky tuottaa tietoa ja siten tiedon avulla kehittää ja muokata omaa alaansa.

Ulkoisen määrittelyn sijasta asiantuntijuuden voi määritellä myös sisäisenä kokemuksena (Isopahkala-Bouret 2008). Asiantuntijuus on tieteelliseen ja ammatilliseen tietoon perustuvaa professionaalisuutta, joka auttaa monimutkaisissa tilanteissa henkilöitä suunnistamaan, kyseenalaistamaan, ottamaan tuntumaa tai tuomaan uusia näkökulmia tilanteisiin, joihin ei ole valmiita reseptejä. Isopahkala-Bouretin (2008) mukaan kokemus asiantuntijuudesta muodostuu asiaan kuuluvasta tietämyksestä, tilannesidonnaisesta kyvystä toimia sekä luottamuksen ja varmuuden tunteesta.

Tutkimustiedon välittäminen ei ole yliopistojen akateemisten asiantuntijoiden yksinoikeus. Muun muassa tutkimuslaitosten, ministeriöiden ja kansalaisjärjestöjen asiantuntijat tuottavat, analysoivat ja kokoavat tutkimustietoa päätöksenteon tueksi. Tärkein sote-uudistuksen tieteellinen asiantuntijataho on ollut Terveyden ja hyvinvoinnin laitos, joka on muun muassa julkaissut lukuisia arviointiraportteja sote-uudistuksen eri vaiheissa (esim. THL 2013; Erhola ym. 2014). Sektoritutkimuslaitosten asiantuntemus ei ole kuitenkaan samalla tavalla hallituksesta ja ministeriöistä riippumatonta kuin yliopistojen edustajien asiantuntemus, eikä siihen liity välttämättä omien tutkimustulosten tuottamista.

Akateeminen asiantuntijuus pohjautuu pitkäkestoiseen koulutukseen, asiantuntijuutta ylläpitäviin instituutioihin (yliopistot ja korkeakoulut) sekä auktoriteettiaseman periaatteisiin (Lammintakainen ym. 2018). Akateemisessa maailmassa sovelletaan asiantuntijuuden määrittelyyn ennalta sovittuja käytäntöjä (Väliverronen 2016, 52), joissa korostuu kyky tuottaa oman alansa tutkittua tietoa (vrt. Collinsin \& Evans 2007). Yliopistoissa pysyviin tutkija- ja opettajatehtäviin voidaan esimerkiksi nimittää vain tutkijakoulutuksen suorittaneita henkilöitä. Dosentuurin saamisen edellytyksenä on, että hakijalla on perusteelliset tiedot omalta alaltaan, julkaisuilla tai muilla tavoin osoitettu kyky itsenäiseen tieteelliseen tutkimustyöhön sekä hyvä opetustaito. Tutkimustulosten ja hakijoiden pätevyys varmistetaan vertaisarvioinnilla. Akateemiseen asiantuntijuuteen kuuluu totuuden etsintä parhaiden mahdollisten menettelytapojen avulla (Lammintakainen ym. 2018).

Virtanen ja kumppanit (2015) ovat kiinnittäneet huomiota tieteenala-asymmetriaan poliittishallinnollisessa päätöksenteossa tarvittavan tiedon tuottamisessa. Tämä viittaa siihen voidaanko akateemisella kentällä tuottaa päätöksenteon tarpeita silmällä pitäen riittävän tarkoituksenmukaista ja nyansoitua tietoa ottaen huomioon tuotetun tiedon tieteenalarajoitteet. Sote-uudistuksen keskeinen tavoite on yhdistää sosiaali- ja terveysalan osaamista, joka on tällä hetkellä eriytynyt myös akateemisella kentällä. Perinteisesti terveysalan tutkimus on paikantunut Suomessa lääketieteeseen, terveystieteeseen ja hoitotieteeseen, jossain määrin myös väestötieteeseen. Sosiaalialan yliopisto-opetusta on annettu sosiaalityössä ja sosiaalipolitiikassa (tosin sosiaalipolitiikka tutkii myös terveyspoliittisia järjestelmiä). Näiden lisäksi sote-uudistus liittyy ainakin hallintotieteeseen, oikeustieteeseen (erityisesti 
sosiaalioikeuteen) sekä terveystaloustieteeseen ja jopa liiketaloustieteeseen (etenkin valinnanvapausmallien syntymisen jälkeen).

Edellä sanotusta seuraa, ettei ole olemassa kattavaa sote-osaamista ilmentävää akateemista tutkintoa tai työnimikettä ja ettei yksikään akateeminen sote-asiantuntija hallitse kaikkia relevantteja tieteellisiä näkökulmia sote-uudistukseen. Lisäksi on otettava huomioon, että yhteiskunnallisen työnjaon syventyessä asiantuntemus jakautuu yhä kapeammille erikoisaloille, eikä niin kutsuttu laaja-alainen asiantuntijuus ole välttämättä enää mahdollista. Se ei ole mahdollista etenkään silloin, jos tutkijat valitsevat kapean asiantuntijaroolin, johon kuuluu autonomian puitteissa vain tutkijoiden itse asettamiin kysymyksiin vastaaminen ja johon ei kuulu muiden kuin omien tutkimusten tulosten tulkitseminen julkisuudessa (Väliverronen 2016, 61).

Sote-uudistuksen erilaiset vaiheet ja painotukset ovat myös vaikuttaneet tarvittavaan asiantuntemukseen. Esimerkiksi valinnanvapausmalli korosti terveyspalvelumarkkinoiden osaamista.

Työelämän tehtävät jaetaan perinteisesti tavallisiin ammatteihin ja yhteiskunnallisiin asiantuntija-ammatteihin, joita kutsutaan professioiksi (Väliverronen 2016, 52). Professioita määrittää korkea koulutus, itsenäisyys, eettiset säännöt, oma ammattijärjestö ja epäitsekäs yhteiskunnallinen palvelutehtävä (vrt. Abbot 1988). Yksi tapa määritellä sote-asiantuntijuus on liittää se sote-alan professiohin. Professio edustaa rationaalisuutta, loogisuutta ja tieteellisyyttä. Tärkeä profession ominaisuus on se, että se pohjautuu omaan, selkeästi rajattuun tieteenalaan. Selkein sote-alan professio on lääkäriammatti (Erhola ym. 2019). Se on kiistatta arvotettu, jopa arvostetuin ammatti Suomessa. Vuonna 2018 Suomen Kuvalehden mielipidetutkimuksessa kymmenen arvostetuimman ammatin listassa mainittiin kahdeksan lääkärin ammattinimikettä ja yksi muu terveysalan ammatti (kätilö). Lääkäriammatti ei tuo kuitenkaan automaattisesti sote-asiantuntijuutta, sillä lääkärikoulutukseen kuuluu hyvin vähän opetusta sosiaalialasta tai muistakaan yhteiskunnallisista oppiaineista.

Sote-alan professiot toimivat muiden professioiden tavoin paitsi sosiaalisen kontrollin välineenä ja yhteiskuntaa koossa pitävänä voimana myös itsenäisinä vallankäyttäjinä. Professiot ei- vät ole siis vain autonomisia ja itseään ohjaavia instituutiosta, joiden altruistiset jäsenet työskentelisivät automaattisesti mahdollisimman tehokkaasti yhteiseksi hyväksi. Ammattikunnat ovat perinteisesti työskennelleet saadakseen itselleen sosiaalista statusta ja legitimoidun aseman yhteiskunnassa. Tässä retorisessa kamppailussa toimijat pyrkivät pesemään pois tai häivyttämään omat intressinsä ja niiden sijaan vetoamaan yleiseen etuun.

Tunnustetun asiantuntemuksen ja auktoriteetin voi hankkia myös muiden kuin professioiden tai akateemisen pätevöitymisen kautta, esimerkiksi työskentelemällä sote-alan johtotehtävissä. Tällöin asiantuntijan näkemykset saattavat heijastaa enemmän kyseiseen tehtävään liittyviä erityisintressejä kuin objektiivisuuteen pyrkivää akateemista asiantuntemusta. Tällaisiin epäsuoriin intressikonflikteihin tunnutaan suhtauduttavan Suomessa sallivasti (mikä johtunee siitä, että kyseessä on pieni maa). Johtamistehtävissä hankittu asiantuntemus ei väistämättä estä asiantuntijaa tarkastelemasta uudistuksen kohteena olevaa kysymystä laajemmasta näkökulmasta. Ulkopuolisten on kuitenkin vaikeaa tai jopa mahdotonta erottaa kohtia, joissa mielipiteet pohjautuvat oman organisaation edun ajamiseen. Edellä asiantuntijuutta on lähestytty yksilön ominaisuutena. Asiantuntijuus voidaan kuitenkin ymmärtää myös kollektiiviseksi. Tällöin toiminta synnyttää rakenteita ja toimijoita, eikä päinvastoin (Koivunen 2005).

\section{MENETELMÄ JA AINEISTO}

Tutkitun tiedon käyttöä päätöksenteossa voi arvioida sen mukaan miten poliittisia päätöksiä perustellaan. Vuonna 1877 ilmestyneessä artikkelissaan "The Fixation of Belief" Charles S. Peirce (1877) määritteli neljä erilaista tapaa hankkia tietoa tai muodostaa käsityksiä (ks. myös Ansell \& Geyer 2017). Itsepäisyyden menetelmässä aiemmin hankituista uskomuksista pidetään kiinni todisteista ja kritiikistä välittämättä. Auktoriteetin menetelmässä uskomuksia perustellaan jonkin auktoriteetin mielipiteellä kyseenalaistamatta sen oikeutusta. Intuitiivisessa menetelmässä uskomusta perustelee se, että se vaikuttaa intuitiivisesti selvältä. Tieteellinen menetelmä perustuu objektiivisuuteen, julkisuuteen ja itseään korjaavaan mekanismiin. 
Perustelutapoja voivat käyttää yksilöt, ryhmät tai organisaatiot (instituutiot).

Peircen itsepäisyyden menetelmässä uskomuksia ei tarvitse perustella. Menetelmä toimii sitä paremmin, mitä polkuriippuvaisempia kannanotot ovat: perinteeseen tukeutuminen ei vaadikaan niin paljon perusteluita kuin uudistus, erityisesti radikaali uudistus. Poliitikoille itsepäisyys voi olla tarpeellista, sillä muutoin monimutkaista ja vaikeaa lakikokonaisuutta ei pystytä ajamaan läpi poliittisessa prosessissa. Itsepäisyyden menetelmä liittyy ennen muuta juuri poliitikkojen ja eturyhmien toimintaan, jossa korostuu hallituksen, etujärjestön, puolueen tai yrityksen kannan puolustaminen todisteista ja kritiikistä välittämättä. Ongelmia muodostuu silloin, jos menetelmää käytetään liian yksipuolisesti välittämättä muista uskomusten perustelutavoista.

Itsepäisyyden menetelmä ei anna juuri roolia asiantuntijoille, sillä nimensä mukaisesti menetelmässä ei tarvita uskomuksen perustelemiseen asiantuntemusta. Voidaan toki ajatella joidenkin asiantuntijoiden, myös akateemisten asiantuntijoiden, käyttävän tätä menetelmää, jos he ovat jossain vaiheessa lyöneet lukkoon kantansa ja puolustavat sitä itsepäisesti, vaikka asiaperusteet uskomukselle ovat kadonneet esimerkiksi uusien tutkimustulosten tai olosuhteiden muuttumisen seurauksena. Julkisessa keskustelussa itsepäisyyden menetelmä voi saada huomiota tasapuolisuusharhan ansiosta. Toimittajat voivat asettaa vastakkain itsepäisesti oman ryhmänsä kantaa puolustavan keskustelijan sekä tutkittuun näyttöön mielipiteensä perustavan keskustelijan.

Auktoriteetin menetelmässä auktoriteetti perustuu tunnustettuun asiantuntemukseen. Akateemisen asiantuntemuksen näkökulmasta ongelmallista on kuitenkin se, että auktoriteetti voi perustua myös muuhun kuin asiantuntemukseen. Akateemiset tittelit kertovat ulospäin tieteellisestä auktoriteetista muttei välttämättä asiantuntemuksesta, mihin pilkallinen toteamus "päivystävistä dosenteista" myös viittaa. Akateeminen asiantuntija on voinut hankkia auktoriteettiasemansa myös jollain muulla alalla kuin sillä, jossa hän esiintyy auktoriteettina tai jossa hänen auktoriteettiasemaansa viitataan.

Peircen kolmas menetelmä on intuitio. Menetelmä olisi helppo sivuuttaa väittämällä, että intuitioon luottavat vain tietämättömät maallikot ja että asiantuntijaksi ei hyväksytä sitä, joka perustelee uskomuksensa vain intuitiolla. Todellisuudessa asiantuntijuus ja siihen ankkuroidut lausunnot saattavat - erityisesti monimutkaisissa kysymyksissä - kummuta intuitiosta, joka puolestaan voi pohjautua esimerkiksi ammattiidentiteettiin, koulutukseen tai poliittiseen orientaatioon.

Peircen neljäs uskomuksia perusteleva menetelmä on tieteellinen menetelmä. Siinä asiantuntemus perustuu objektiivisuuteen, julkisuuteen ja itseään korjaavaan mekanismiin. Tieteellisen menetelmän käyttö tuo parhaiten esiin akateemisen asiantuntijuuden. Nykykäsityksen mukaan uusia tutkimustuloksia syntyy vertaisarvioitujen julkaisuiden avulla. Tieteellinen menetelmä sote-uskomusten perustelemisessa vaatii siis vertaisarvioitujen tutkimusten julkaisemista aihepiiristä tai ainakin tutustumista niihin. Tutkimus etenee kuitenkin hitaasti eikä tieto aina kumuloidu. Lisäksi tieto on - kuten edellä todettiin - hajallaan eri tieteenaloilla.

Akateemisia asiantuntijoita on ollut mukana monissa sote-uudistuksen vaiheissa ja monissa erilaisissa ryhmissä. Analyysin kohteeksi on valittu:

- Paras-hankkeen valmistelu,

- palvelurakennetyöryhmä,

- järjestämislakityöryhmä,

- parlamentaarisen valmistelun asiantuntijaryhmä,

- STM:n asiantuntijaryhmä sekä

- sote-asiantuntijoiden kuuleminen perustuslakivaliokunnassa (taulukko 1).

Analyysikohteet on valittu siksi, että ne ovat linjanneet keskeisesti sote-uudistuksen etenemistä ja niissä on korostunut (tai olisi pitänyt korostua) sote-asiantuntijuuden tarve eikä esimerkiksi yleisen hallinnon, rahoituksen tai lainsäädännön (ml. perustuslain) tuntemus. Tämän tutkimuksen primääriaineistona käytetään asiantuntijaryhmien ja eduskuntakuulemisten kokousmuistiinpanoja (taulukko 1). Olen toiminut edellä kuvatuista työryhmistä palvelurakennetyöryhmän, järjestämislakityöryhmän, parlamentaarisen valmistelun asiantuntujaryhmän sekä STM:n sote-asiantuntijaryhmän jäsenenä sekä kutsuttuna asiantuntijana kahdessa kuvatussa perustuslakivaliokunnan kuulemisessa. 
Taulukko 1. Artikkelissa käytetyt aineistot.

\begin{tabular}{|c|c|}
\hline $\begin{array}{l}\text { Primääri- } \\
\text { aineisto }\end{array}$ & $\begin{array}{l}\text { Läsnäolijan muistiinpanot palvelurakennetyöryhmän, järjestämislakityöryhmän, } \\
\text { parlamentaarisen valmistelun asiantuntujaryhmän ja STM:n sote-asiantuntijaryhmän } \\
\text { kokouksista sekä perustuslakivaliokunnan kuulemisista 1.6.2017 ja 13.4.2018. }\end{array}$ \\
\hline \multirow[t]{7}{*}{$\begin{array}{l}\text { Sekundääri- } \\
\text { aineisto }\end{array}$} & $\begin{array}{l}\text { Työryhmäraportit (Brommels ym. 2016; Erhola ym. 2013; STM 2011; STM 2012a; } \\
\text { STM 2012b; STM 2013; STM 2015a; STM 2015b) }\end{array}$ \\
\hline & $\begin{array}{l}\text { Sote-uudistusta kommentoiva kirjallisuus (Erhola ym. 2019; Hiilamo 2015; 2020; } \\
\text { Valli-Lintu 2017, 2019; Välimäki 2013) }\end{array}$ \\
\hline & Sote-uudistuksen arvioinnit (Erhola ym. 2014; Manssila ja Mattson 2019; THL 2013) \\
\hline & Lausunto ja selonteko (Lehtonen ym. 2018; Valtiovarainministeriö 2009) \\
\hline & Uudistuksen tausta-aineisto (Jonsson 2017) \\
\hline & Hallitusohjelma (Sipilä 2015) \\
\hline & Asiatuntijaraporttit (THL:n asiantuntijaryhmä 2011; 2012) \\
\hline
\end{tabular}

Tutkimuksen aineisto koostuu pääasiassa sekundaarilähteistä, jotka kuvaavat akateemisten sote-asiantuntijoiden roolia sote-uudistuksen eri vaiheissa. Aineistona käytetään valmisteluryhmien raportteja (STM 2011, 2012a, 2012b, 2013, 2015a, 2015b; Brommels ym. 2016), arviointiryhmien raportteja (THL:n asiantuntijaryhmä 2012; THL 2013; Erhola ym. 2013, 2014; Manssila \& Mattson 2019), asiantuntijatyöryhmien lausuntoja (Lehtonen ym. 2018), poliittisia linjauksia (Valtiovarainministeriö 2009) sekä uudistusta kommentoivaa kirjallisuutta (esim. Erhola ym. 2019; Pekurinen ym. 2011; ValliLintu 2017, 2019).

Lisäksi tarkastelen sote-asiantuntijoiden roolia kahdessa perustuslakivaliokunnan kuulemisessa (vrt. Valli-Lintu 2019). Sote-asiantuntijoita on kuultu uudistuksen eduskuntakäsittelyn yhteydessä monissa muissakin valiokunnissa, ennen muuta sosiaali- ja terveysvaliokunnassa. Aikaisemman kirjallisuuden perusteella sote-uudistuksen kohtalon kannalta ratkaisevaksi muodostui käsittely perustuslakivaliokunnassa (esim. Valli-Lintu 2017, 2019), minkä vuoksi tutkimuksessa keskitytään perustuslakivaliokuntaan ja siinä kahteen keskeiseen kuulemiseen. Primäärija sekundaariaineiston triangulaatio auttaa syventämään kuvaa asiantuntijatiedon käytöstä ja asiantuntijoiden roolista mainituissa sote-uudistuksen vaiheissa.

Analyysi on toteutettu kolmella eri tasolla ja kolmessa eri vaiheessa. Ensimmäinen taso koskee toimijoita, toinen työryhmien toimintaa ja kolmas työryhmien lopputuloksia. Ensimmäisessä vaiheessa käytiin läpi edellä kuvatussa sekundääriaineistossa esiintyvien työ-, valmistelu- ja kuulemisryhmien asiakirjat, joista selvitettiin ryhmien kokoonpano. Tässä yhteydessä analysoitiin akateemisten asiantuntijoiden määrää ja osuutta toimijoiden joukossa. Toisessa vaiheessa analysoitiin kokousmuistiinpanojen, osallistuvan havainnoinnin ja sote-uudistusta kommentoivan kirjallisuuden avulla Peircen kategorioiden mukaisten uskomusten perustelutapojen esiintymistä ryhmien toiminnassa. Analyysikeinona oli argumentaatioanalyysi, jossa tarkastelun kohteena olivat sote-uudistusta koskevien keskeisimpien ehdotusten (sote-järjestäjien lukumäärä, järjestäjien rahoitus, valinnanvapauden rooli sote-palveluissa) perustelutavat (vrt. Nieminen ym. 2019; Palukka ym. 2017). Kolmannessa vaiheessa analysoitiin argumentaatioanalyysin keinoin ryhmien raporteissa käytettyjä uskomusten perustelutapoja.

\section{ANALYYSI}

\section{Paras-hanke}

Keskustapuolueen johtama Vanhasen I hallitus aloitti 2005 kehittämishankeen, joka sai nimen Paras (Valtiovarainministeriö 2009). Parashankkeella ei ollut akateemista asiantuntijaryhmää, mutta muutoin valmistelu oli erittäin laajapohjaista. Hanketta johti erillinen ministerityöryhmä, mutta sen käytännön toteutuksesta vastasi parlamentaarinen kunta- ja palvelurakenneryhmä. Ryhmässä oli mukana Suomen Kuntaliiton hallituksessa edustettuina olevat puolueet sekä sisäasiainministeriön, valtiova- 
Taulukko 2. Akateemisten sote-asiantuntijoiden osallistuminen ja uskomusten perustelutavat sote-uudistuksen eri vaiheissa.

\begin{tabular}{|l|l|l|l|}
\hline Valmisteluvaihe & Ajankohta & $\begin{array}{l}\text { Akateemisten sote- } \\
\text { asiantuntijoiden } \\
\text { osallistuminen }\end{array}$ & $\begin{array}{l}\text { Tärkeimmät } \\
\text { uskomusten } \\
\text { perustelutavat }\end{array}$ \\
\hline Paras-hanke & $2005-2008$ & Olematonta & Itsepäisyyden menetelmä \\
\hline Palvelurakennetyöryhmä & 2012 & Melko vähäistä & Itsepäisyyden menetelmä \\
\hline Järjestämislakityöryhmä & 2013 & Melko vähäistä & $\begin{array}{l}\text { Itsepäisyyden menetelmä } \\
\text { ja auktoriteetin } \\
\text { menetelmä }\end{array}$ \\
\hline $\begin{array}{l}\text { Parlamentaarisen valmistelun } \\
\text { asiantuntijaryhmä }\end{array}$ & 2014 & Vähäistä & Itsepäisyyden menetelmä \\
\hline $\begin{array}{l}\text { STM:n asiantuntijaryhmä } \\
\text { Peruslakivaliokunnan I kuuleminen }\end{array}$ & 1.6 .2017 & Laajaa & $\begin{array}{l}\text { Auktoriteetin menetelmä } \\
\text { ja tieteellinen } \\
\text { menetelmä }\end{array}$ \\
\hline Peruslakivaliokunnan I kuuleminen & 13.4 .2018 & Laajaa & Auktoriteetin menetelmä \\
\hline
\end{tabular}

rainministeriön, sosiaali- ja terveysministeriön ja opetusministeriön virkamiesjohto sekä Suomen Kuntaliitto. Alkuvaiheen maakunnallisiin seminaareihin osallistui yhteensä noin 6000 henkilöä (Valtiovarainministeriö 2009).

Paras-hankkeen tavoitteena oli, että sosiaalija terveyspalvelut järjestettäisiin yhdessä ja vähintään 20000 asukkaan väestöpohjalla. Mainittu asukasmäärä oli keskeinen kantokykyvaatimus. Järjestäjien lukumäärän odotettiin laskevan 240:stä noin 140:een. Ennen Paras-hanketta Suomessa oli 444 kuntaa. Hankkeen aikana kuntien määrä väheni reilulla sadalla 336 kuntaan. Paras-laki oli voimassa vuoden 2012 loppuun, mutta Jyrki Kataisen hallitus pysäytti hankkeen jo vuonna 2011. Tuolloin maassa oli vielä noin 50 kuntaa, jotka eivät täyttäneet Paras-hankkeen määrittelemiä kantokykyvaatimuksia.

Hankeen seurauksena Suomeen syntyi erittäin monimutkaisia kuntien yhteistoiminta- ja ulkoistusjärjestelyitä, joita kutsutaan hyvällä syyllä "hallintohimmeleiksi". Vuonna 2015 Suomessa oli 151 julkisen terveydenhuollon järjestäjä: 87 kuntaa, 31 kuntayhtymää ja 33 vastuukuntamallilla toimivaa yhteistoiminta-aluetta. Yhteensä 56 järjestäjää vastasi palveluista alle 20000 asukkaalle (Jonsson 2017).

Paras-hankkeen ensimmäinen vaihe pohjautui yksityiskohtaiseen poliittiseen sopimukseen, joka ohjasi uudistuksen toteuttamista. Kokenut sote-virkamies Auli Valli-Lintu $(2017,8)$ kuvaa kirjassaan Sote- ja kuntarakenteen pitkä kujanjuoksu havainnollisesti, mitä itsepäisyyden menetelmä tarkoitti tuolloin käytännön lainvalmistelussa: "Lakimuotoon kirjoitettu yksityiskohtainen poliittinen sopimus vaikeutti osaltaan normaalia lainsäädäntövalmistelua. Lakimuoto tarkoitti, että lain muuttaminen oli äärimmäisen vaikeaa ja perustelut valitulle ratkaisulle ja niiden tarkoituksenmukaisuudelle piti perustella jälkikäteen. Ratkaisut eivät perustuneet siten laajaan virkamiesvalmisteluun tai etukäteen tehtyyn vaihtoehto-tarkasteluun tai intressipunnintaan." Akateemisilla asiantuntijoilla ei ollut juuri lainkaan roolia Paras-hankkeen valmistelussa. Se perustui ennen muuta itsepäisyyden menetelmän käyttöön. Tätä kuvaa Valli-Linnun toteamus siitä, että perustelut poliittisessa sopimuksessa määritellyille ratkaisuille piti löytää jälkikäteen.

\section{Palvelurakennetyöryhmä}

Paras-hanke osoitti, ettei laajapohjaisesti valmisteltu mutta vapaaehtoisuuteen perustuva uudistus ratkaissut sote-palveluiden järjestämisen ja rahoituksen ydinongelmaa. Jyrki Kataisen/ Alexander Stubbin hallitukset pyrkivät vuosina 2011-2015 ratkaisemaan sote-palveluiden järjestämisen ja rahoittamisen ydinongelmaa 
vahvojen peruskuntien, sote-alueiden ja erityisvastuualueiden avulla. Kataisen sote-uudistus oli tarkoitus toteuttaa siten, että ensin perustettiin työryhmä, joka hahmotteli hallintomalleja (palvelurakennetyöryhmä). Sen pohjalta aloitti työnsä toinen työryhmä, joka hioi yksityiskohdat ja teki lakiesityksen (järjestämislakityöryhmä).

Virkamiestasolla sote-uudistuksen valmistelu alkoi jo edellisen hallituskauden lopulla. STM:n valmistelutyöryhmään kuului 31 virkamiestä, sote-johtajaa ja muiden sidosryhmien edustajaa. Yliopistojen sote-asiantuntijat eivät olleet mukana, mutta muutoin ryhmä edusti monipuolisesti sote-alan osaamista Suomessa. Huhtikuussa 2011 - juuri eduskuntavaalien jälkeen - ryhmä julkaisi raportin sosiaali- ja terveydenhuollon järjestämistä, selvittämistä ja valvontaa koskevan lainsäädännön peruslinjauksista (STM 2011). Tämä oli ensimmäinen kerta, kun ministeriö pohjusti sote-valmistelua laajapohjaisen asiantuntijaryhmän avulla. Aikaisemmat THL:n asiantuntijaryhmät $(2011,2012)$ oli muodostettu laitoksen sisältä. STM:n valmisteluryhmä esitti mallia, jossa noin 20 suurta kuntaa järjestäisi sote-palvelut vastuukuntaperiaatteella. Mallin keskeinen ajatus oli se, että vahvassa kunnassa sosiaali- ja terveydenhuollon päätöksenteko yhdistyisi kunnan muuhun päätöksentekoon. Malli ei saanut poliittista kannatusta, eikä se ollut esillä kevään 2011 hallitusneuvotteluissa (Hiilamo 2015) mutta malli jäi itämään valmistelijoiden ajatuksiin ja vaikutti sote-uudistuksen myöhempiin vaiheisiin.

Keväällä 2012 aloittaneen palvelurakennetyöryhmän tavoitteena oli uudistaa sosiaali- ja terveydenhuollon palvelurakenne "vastaamaan tulevaisuuden tarpeita huomioiden erityisesti väestön palvelutarpeet, julkisen talouden kestävyys ja tulevaisuuden kuntarakenne" (STM 2012a, 2012b). Ryhmän 28 jäsentä edustivat monipuolisesti erilaisia sidosryhmiä ja soteosaamista. Ryhmän työtä tuki 16 hengen virkamiessihteeristö. Poliittiset tahot vaikuttivat työryhmän jäsenten valintaan. Mukana ei edelläänkään ollut juuri lainkaan akateemisia soteasiantuntijoita. Noin puolet ennen vaaleja työskennelleen työryhmän (STM 2011) jäsenistä jatkoi tämän ryhmän jäseninä.

Palvelurakenneryhmän sote-asiantuntijoiden lähes yksimielisen näkemyksen mukaan parem- pien palveluiden järjestäminen vaatisi vähintään 200000 hengen väestöpohjan. Luku mainittiin jatkuvasti eri yhteyksissä - osin ehkä siksi, että sairaanhoitopiirien väestöpohja on suurin piirtein 200000 asukasta ja siksi että ympärivuorokautisen sairaalapäivystyksen järjestäminen vaatisi tämänkokoisen väestöpohjan.

Kataisen hallitusohjelmassa sote-uudistus oli kytketty kuntauudistukseen, mikä vaikeutti palvelurakennetyöryhmän toimintaa. Hallituksen tavoitteena oli yhdistää maaseudun pienet kunnat vähintään 20000 asukkaan kokoisiksi ja samanaikaisesti liittää keskuskaupunkien parasiittimaiset ympäryskunnat keskuskaupunkiin. Näin syntyisi "vahvoja peruskuntia", jotka tuottaisivat sote-palvelut paitsi omille asukkailleen myös maaseudun uusille kunnille. Uudistus olisi mullistanut perusteellisesti kuntakentää: yli 300 kuntaa oli tarkoitus tiivistää 70 suurkuntaan. Mallissa ei ollut perustuslaillista ongelmaa, sillä palveluiden rahoituksesta ja järjestämisestä olisi vastannut edelleenkin kunta, nyt vain selvästi vahvempi kunta.

Palvelurakennetyöryhmän asiantuntijat halusivat kuitenkin sote-uudistusta, joka ei olisi alisteinen kuntauudistukselle. Muutaman kuukauden työskentelyn jälkeen palvelurakennetyöryhmä antoi kesäkuussa 2012 yksimielisen väliraportin, jossa se esitti toimeksiantonsa mukaisesti kolmea erilaista mallia uudeksi sote-rakenteeksi: A-mallissa oli noin 70 kuntaa, jotka vastaisivat laajennetuista peruspalveluista itsenäisesti, B-mallissa noin 30-50 vanhempaa kuntaa ja sote-aluetta vastaisi laajennetuista peruspalveluista (kuntien määrä voisi olla väliltä 30 350) ja C-mallissa 12-17 sote-aluetta vastaisivat perustason ja erityistason palveluista (kuntien määrä voisi olla väliltä 12-350) (STM 2012a).

Loppukesästä 2012 työryhmän puheenjohtaja, sosiaali- ja terveysministeriön kansliapäällikkö Kari Välimäki esitteli C-vaihtoehtoa selvästi rohkeamman mallin, jossa 20 kuntaa tuottaisi palvelut vastuukuntaperiaatteella (Välimäki 2013). Alueet vastaisivat kaikista palveluista, myös erityistason palveluista. Yliopistosairaaloiden ympärille rakennetuille erityisvastuualueille jäisi vain koordinaatiotehtäviä. Malli oli suurin piirtein sama kuin se, johon Välimäen johtama työryhmä oli päätynyt edellisvuoden keväällä (STM 2011). Malli ei saanut nytkään poliittista kannatusta. 
Tässä vaiheessa virkamies- ja käytännön asiantuntemukseen perustuva näkemys ajautui täydellisesti törmäyskurssille poliittisesti motivoitujen sote-linjausten kanssa (Hiilamo 2015). Poliitikkojen itsepäisyyteen perustuva menetelmä syrjäytti käytännön asiantuntemukseen perustuvan auktoriteetin menetelmän. Tämä todettiin melko suoraan loppuraportin johdantoluvussa, jossa todettiin: "Koska poliittiset linjaukset ovat rajanneet työryhmän toimeksiantoa, eivät ehdotukset perustu puhtaaseen asiantuntijanäkemykseen vaan ehdotuksessa on pyritty annettujen linjausten puitteissa hakemaan poliittisesti toteutettavissa olevaa ratkaisua" (STM 2012b, 11). Itsepäisyyden menetelmän käytöstä kertoo myös se, että STM:n alainen asiantuntijalaitos THL jätti raporttiin eriävän mielipiteen.

\section{Järjestämislakityöryhmä}

Sote-uudistuksen valmistelu jatkui järjestämislakityöryhmän perustamisella (STM 2013). Ryhmään valittiin 25 jäsentä, joista noin kaksi kolmasosaa oli ollut mukana jo palvelurakennetyöryhmässä. Uudet jäsenet edustivat edellisten ryhmien tapaan pääasiassa käytännön sote-johtamisen asiantuntemusta. Lisäksi ryhmässä oli viiden hengen valmisteluryhmä sekä 18 hengen pysyvien asiantuntijoiden ryhmä (pääosin virkamiehiä) ja viiden hengen teknisten sihteereiden ryhmä. Ryhmä asetti neljä erillisiä jaostoa, joissa oli lisää asiantuntijoita.

Valmisteluun oli vuosina 2011-2013 osallistunut mainituissa työryhmissä ja niiden alaryhmissä nimitettyinä asiantuntijoina noin sata henkeä. Merkille pantavaa on se, että poliittisesti ohjatuilla virkamiehillä oli keskeinen rooli valmistelussa, mikä korosti itsepäisyyden menetelmää. Uskomuksia perusteltiin myös auktoriteetin menetelmällä. Lähes kaikki ulkopuoliset asiantuntijat olivat pääasiassa johtamistehtävissä toimivia käytännön ammattilaisia. Heillä oli runsaasti käytännön kokemusta ja samaan aikaan he olivat uudistuksen kohteena olevien sote-organisaatioiden palveluksessa ja siten asianosaisia. Toisin sanoen suunnitellut muutokset olisivat vaikuttaneet kyseisten henkilöiden työnantajaorganisaatioiden tai heidän edustamiensa organisaatioiden toimintaan.

\section{Parlamentaarisen valmistelun asiantuntijaryhmä}

Tammikuun 2014 alussa THL julkaisi kannanoton, jonka mukaan "sosiaali- ja terveyspalvelut hyötyvät laajasta väestöpohjasta". THL:n mukaan "kansainvälinen kokemus kertoo, että vasta noin 200 000-400 000 asukkaan väestöpohja riittää turvaamaan laadukkaat ja vaativat palvelut. Suomeen tällaisia palveluiden järjestämisestä, tuottamisesta ja rahoituksesta vastaavia alueellisia kokonaisuuksia mahtuisi noin 15-20". Kannanotossa korostettiin, että riittävän suuret alueet ovat keino vahvistaa peruspalveluita ja integroida perus- ja erikoisterveydenhuoltoa.

Vähän tämän jälkeen julkisuudessa oli esillä malleja, joissa sote-uudistus olisi toteutettu uudistamalla vain erikoissairaanhoitoa siirtämällä se viidelle yliopistosairaala-alueelle (Uimonen 2015). Pattitilanteessa kaikki puolueet päättivät keväällä 2014 yrittää yhdessä viiden alueen mallia, joka oli silloisen oppositiojohtaja Juha Sipilän aloite. Mallin ideana oli siirtää sote-palveluiden järjestämisvastuu viidelle yliopistosairaalan alueelle ja antaa kuntien toimia palveluiden tuottajina. Malli perustui vahvaan tieteelliseen auktoriteettiin. Sen taustalla oli emeritusprofessori Martti Kekomäen idea ja taustatyö (Uimonen 2015).

Viiden alueen mallia valmisteltiin parlamentaarisessa ohjausryhmässä. Ohjausryhmän tukena toimi asiantuntijaryhmä, jossa oli mukana tällä kertaa pääasiassa akateemisia sote-asiantuntijoita, joista useimmat olivat sote-alan professoreita. Asiantuntijaryhmällä ei ollut juurikaan roolia valmistelussa, joka oli vahvasti poliitikkojen ja virkamiesten käsissä. Ryhmän harvoissa kokouksissa virkamiehet kertoivat uudistuksen vaiheista ja sen kohtaamista ongelmista. Viimeistään tässä vaiheessa akateemiset soteasiantuntijat alkoivat kuitenkin saada keskeistä asemaa julkisessa sote-keskustelussa. Soteuudistuksen haparoinnista tuli tärkeä poliittinen kysymys, joka loi mediassa kysyntää soteuudistuksen valmistelua kritisoineille professoreille ja muille asiantuntijoille (vrt. Merikanto 2018b).

Parlamentaarisen ohjausryhmän työtä luonnehti itsepäisyyden menetelmä. Työskentely perustui poliittiseen sopimukseen, jonka reunaehtoja ei haluttu purkaa. Valli-Linnun $(2017,27)$ 
arvion mukaan poliitikot ajoivat jälleen itsepäisesti virkamiehistä välittämättä mallia maaliin: "Lainvalmistelussa tuotiin virkamiestaholta esiin, että esitykseen liittyi perustuslakiongelmia kunnallisen itsehallinnon ja kansanvaltaisuuden toteuttamisen osalta. Kun esityksen takana oli kuitenkin parlamentaarisesti valmistellut linjaukset, esityksen ei ilmeisesti ajateltu kohtaavan perustuslakiongelmia perustuslakivaliokunnan käsittelyssä." Parlamentaarinen ohjausryhmä ei sekään päässyt maaliin, sillä perustuslakivaliokunta tyrmäsi ensin parlamentaarisen ohjausryhmän esityksen ja sen jälkeen sosiaali- ja terveysvaliokunnan kahdessa viikossa valmisteleman uuden esityksen.

\section{Maakuntamallin asiantuntijaryhmä}

Kesällä 2015 aloittanut Sipilän hallitus asetti heti kolmen hengen selvityshenkilöryhmän laatimaan ehdotuksen sote-järjestäjien määrästä. Ryhmää veti valtiontalouden tarkastusviraston pääjohtaja, toinen jäsen oli apulaiskaupunginjohtaja ja kolmas professori. Ryhmä esitti jo elokuussa sopivaksi sote-palveluiden järjestäjien määräksi 9-12 (STM 2015a). Ryhmän puheenjohtaja Tuomas Pöysti nimettiin sote-projektijohtajaksi.

Sote-asiantuntijoita ja käytännön toimijoita kuullut ja erilaisia hallintomalleja selvittänyt virkamiestyöryhmä päätyi marraskuun 2015 alussa ehdottamaan 12 alueen mallia (STM 2015b). Yllättäen työryhmien ehdotukset eivät kuitenkaan kelvanneet pääministeripuolue Keskustalle. Hallituskriisin uhalla se jyräsi marraskuussa läpi 18:n maakunnan mallin. Jälleen kerran itsepäisyyden menetelmä syrjäytti muut menetelmät uskomusten perustelemiseksi. Päätös herätti huomiota myös siksi, että Sipilän hallituksen ohjelmassa oli sitouduttu vahvistamaan "hallinnonalojen rajat ylittävää, tietoon perustuvaa johtamista ja toimeenpanoa" (Sipilä 2015, 27).

Kokoomus onnistui neuvottelemaan kaksi muutosta maakuntamalliin. Sote-järjestäjiä olisi 15 ja kolme muuta maakuntaa järjestäisivät sotepalvelut tukeutuen toiseen maakuntaan (Manssila \& Mattsson 2019). Toisena toivomuksena Kokoomus sai läpi valinnanvapauden toteuttamisen uudistuksen ensimmäisessä vaiheessa. Ensimmäinen muutos unohdettiin vähin erin perustuslain vastaisena. Sen sijaan valinnanva- pautta koskeva muutos johti uudistuksen vaikeuksiin.

Itsepäisyyden menetelmä korostui, kun hallituspuolueiden edustajat eivät kyenneet antamaan mitään sosiaali- ja terveyspoliittisia perusteluita sille, miksi se päätti siirtää sote-palvelut juuri 18 maakunnalle sekä toteuttaa valinnanvapauden uudistuksen ensimmäisessä vaiheessa. Hallitusohjelmassa valinnanvapaus oli uudistuksen kolmas vaihe. Valinnanvapausmallin valmistelu samanaikaisesti sote-hallinnon uudistamisen kanssa oli puhtaasti poliittinen valinta, joka syntyi hallituskriisineuvotteluiden yhteydessä ilman minkäänlaista asiantuntijavalmistelua. Linjaukset näyttäytyivät poliittisena lehmänkauppana, jossa asiantuntijatiedolla - ei akateemisella eikä muullakaan - ollut merkitystä. Keskusta halusi itselleen mieluisen aluehallintomallin, jossa sille on odotettavissa vahva asema. Kokoomus halusi parantaa yksityisten sote-tuottajien asemaa suhteessa julkisiin tuottajiin.

STM asetti vuoden 2016 alussa asiantuntijaryhmän sote-valmistelun tueksi. Ryhmän jäsenten valinta tapahtui poliittisessa prosessissa, mutta he edustivat voittopuolisesti akateemista asiantuntemusta. Ryhmän tehtävänä oli tukea ja antaa asiantuntemustaan ja näkemyksiään soteuudistuksen varsinaisille valmisteluryhmille. Hallitus puolestaan asetti toisen asiantuntijaryhmän valinnanvapausmallien valmistelemiseksi. Professori Mats Brommelsin työryhmään kuului jäseninä kaksi muuta professoria, sote-johtaja ja ylisosiaalineuvos (Brommels ym. 2016). Brommelsin ryhmä ei kuitenkaan hakenut yhteyttä STM:n asiantuntijaryhmään.

Valinnanvapautta oli kuitenkin valmistelu jo aikaisemmin THL:n aloitteessa Jonottamatta hoitoon (Erhola ym. 2013). Brommelsin työryhmän loppuraportti oli perinteinen työryhmäselvitys, jossa ei viitattu tutkimuskirjallisuuteen. Sen pohjalta hallituksen reformiministerityöryhmä linjasi kesäkuussa 2016, että Suomessa otettaisiin käyttöön peräti neljä valinnanvapauden keinoa eli laajasti perustason palveluita tarjoavat sote-keskukset, suppeamman palveluvalikoiman omatiimit, palvelusetelit ja henkilökohtaiset budjetit (Manssila \& Mattson 2019, 33). Päätös laajensi edelleen huomattavasti sote-uudistuksen vaikeusastetta ja valmistelussa tarvittavaa tietopohjaa. Nyt valmistelussa keskeiseksi tuli sote-markkinoiden osaaminen. 
STM:n asiantuntijaryhmän enemmistö suhtautui kriittisesti hallituksen ajamaan valinnanvapausmalliin. Useimmat sen jäsenet (kuten myös muut sote-asiantuntijat) olivat sitä mieltä, että malli tekisi mahdottomaksi alueellisen järjestäjä-tuottaja -malliin pohjautuvan täysin integroidun mallin toteuttamisen (Lehtonen ym. 2018).

Hallituksella oli käsissään uudistus, jonka valmistelussa päätettiin lopulta esittää muutoksia 294 lakiin ja tuottaa yhteensä 4709 sivua uutta lainsäädäntöä (Valli-Lintu 2019, 8). Eri alojen asiantuntijat tekivät valtakunnan tasolla ja maakunnissa hartiavoimin työtä sote-uudistuksen toteuttamiseksi. Tiedonkulussa oli ongelmia. Sipilän hallituksen sote-uudistuksen loppuraportin mukaan uudistuksen valmistelua leimasi syksyllä 2015 ja keväällä 2016 muuttuvat linjaukset. Raportin mukaan "poukkoileva ja ennakoimaton poliittinen linjausvalmistelu vaikeutti merkittävästi uudistukseen liittyvää säädösvalmistelua ja uudistuskokonaisuuden hallittavuutta" (Manssila \& Mattson 2019, 18). Yli $100 \mathrm{mi}^{-}$ nisteriöiden virkamiestä oli nimetty uudistusta koordinoivan valtioneuvoston yhteisen tilannekeskuksen toimitaan. Maakuntien valmisteluun osallistui vuosina 2018-2019 noin 750 palkattua valmistelijaa. Sote-uudistuksen loppuraportin mukaan eri työryhmissä oli todennäköisesti mukana useita tuhansia asiantuntijoita. (Manssila \& Mattsson 2019, 142).

Valinnanvapaus saattoi näyttäytyä marraskuussa 2015 hallituspuolueiden neuvottelijoille melko harmittomana poliittisena hyvityspisteenä, mutta sillä oli vakavia seurauksia sote-uudistuksen etenemiselle. Akateemiset ja muut soteasiantuntijat hyväksyivät laajasti sen, että vastuu sote-palveluista siirrettäisiin maakunnille ja että maakuntien rahoitus perustuisi valtion myöntämään rahoitukseen. Sen sijaan monet asiantuntijat esittivät heti kriittisiä kysymyksiä siitä, mitä valinnanvapaudella todellisuudessa tavoiteltiin ja miten se tulisi vaikuttamaan perustuslain turvaamaan sote-palveluiden saatavuuteen. STM:n asiantuntijaryhmä kritisoi voimakkaasti valinnanvapauslakiesitystä sen valmistelun aikana (Lehtonen ym. 2018). Asiantuntijoiden kritiikistä huolimatta hallitus vei esityksen valinnanvapauslaiksi eduskuntaan. Valinnanvapauslakiesityksestä muodostui sote-uudistuksen kohtalonkysymys, jonka ratkaisussa akateemisilla sote-asiantuntijoilla oli keskeinen rooli.

\section{Valinnanvapaus perustuslakivaliokunnassa}

Eduskunnassa sosiaali- ja terveysvaliokunta pyysi perustuslakivaliokunnalta $(\mathrm{PeVa})$ lausuntoa sote-lakiesityksistä. PeVassa ei ole erityistä sosiaali- ja terveysalan osaamista. Aikaisemmin valiokunta on kuullut pääasiassa vain perustuslakijuristeja, joilla ei ole erityisosaamista sotepalveluista. Täydentääkseen asiantuntemustaan valiokunta turvautui poikkeuksellisesti soteasiantuntijoiden apuun. Kesäkuun 1. päivänä 2017 perustuslakivaliokuntaan oli harvinaisella tavalla kutsuttu kahdeksan asiantuntijaa, joista kuusi oli STM:n asiantuntijaryhmään kuuluneita professoreita. Asiantuntijat kritisoivat esitystä niin keskeneräiseksi, että se voisi aiheuttaa systeemiriskin ja vaarantaa perustuslain turvaamat riittävät sosiaali- ja terveyspalvelut. Näiden asiantuntijoiden kannanotot, jotka olivat sivuutettu asiantuntijaryhmässä ja lakivalmistelussa, olivat Valli-Linnun $(2017,36)$ mukaan ratkaisevia PeVassa, kun se laati lausuntoaan: "Valiokuntakuulemisessa sote-asiantuntijoiden rooli riskien kuvaajana oli keskeinen ja esitys kaatuikin ennen kaikkea heidän lausuntojensa perusteella. Perustuslakiasiantuntijat nojautuivat pitkälti sote-asiantuntijoiden akateemisen asiantuntemuksen suomalla auktoriteetilla antamiin lausuntoihin uudistuksen riskeistä." Tällä kertaa auktoriteettiin perustuva menetelmä sai yliotteen itsepäisyyden menetelmästä.

\section{Valinnanvapaus uudelleen perustuslakivaliokunnassa}

PeVa:n lausunnon jälkeen hallitus päätti valmistella kokonaan uuden lakiesityksen valinnanvapaudesta. Vastuu valmistelusta annettiin virkamiehille. Uudessa esityksessä piti ottaa huomioon vain ne ongelmat, jotka edellyttivät perustuslakivaliokunnan mukaan muutosta. Virkamiehet tekivät työtä käskettyä ja saivat alkusyksystä 2017 pika-aikataululla valmiiksi esityksen, joka sai myös STM:n asiantuntijaryhmältä varovaisen myönteisen vastaanoton. Hallitus päätti kuitenkin muuttaa esitystä laajentamalla merkittävästi asiakassetelien käyttöä ja ottaa ne käyttöön myös erikoissairaanhoidossa. Asiantuntijoiden keltainen valo vaihtui punaiseksi.

STM pyysi marraskuussa 2017 sote-asiantuntijaryhmän jäseniltä kirjallista arviota valinnan- 
vapauslain esitysluonnoksesta. Ryhmän enemmistö päätti laatia yhteisen lausunnon. Tämä oli ensimmäinen kerta, kun asiantuntijaryhmä laati ja julkaisi yhteisen kannanoton, joka perustui paitsi tieteelliseen auktoriteettiin myös tieteelliseen menetelmään. Lausunnossa oli tutkimusviitteitä ja se julkaistiin myöhemmin katsauksena Sosiaalilääketieteellisessä aikakauskirjassa (Lehtonen ym. 2018).

Joulukuussa 2017 hallitus päätti luopua erikoissairaanhoidon asiakassetelistä vastauksena ankaraan erikoissairaanhoitoa koskevaan kritiikkiin (Valli-Lintu 2019, 15). Tämä tapahtui vasta sen jälkeen, kun asiantuntijaryhmä oli laatinut yhteisen lausuntonsa. Kriittinen lausunto perustui siis versioon, jota hallitus ehti korjata ennen sen esittelemistä eduskunnalle. Kevään 2018 aikana huomattava osa niistä asiantuntijoista, jotka olivat aikaisemmin suhtautuneet yhdessä tuumin kriittisesti sote-uudistusesitykseen, näytti nyt keltaista valoa korjatulle sotemallille (Waris 2018).

Huhtikuun 13. päivänä 2018 perustuslakivaliokunta kuuli seitsemää sote-asiantuntijaa, joista kuusi oli asiantuntijaryhmään kuuluvia professoreita. Kriittisesti valinnanvapausmalliin suhtautuvat professorit olivat yliedustettuina (vrt. Waris 2018). Perustuslakivaliokunnassa kuten muissakin eduskunnan valiokunnissa työskentely perustuu auktoriteetin menetelmän käyttöön. Valiokunnilla ei ole kykyä eikä mahdollisuuksia arvioida tieteellisiä kysymyksiä. Poliittiset näkemykset saavat enemmän tilaa, jos asiantuntijat ovat erimielisiä.

Osin sote-asiantuntijoihin nojautuen $\mathrm{PeVa}$ kirjoitti toisen kriittisen lausunnon valinnanvapauslakiesityksestä. Lisäksi valiokunta kytki perustuslakiasiantuntijoiden lausuntojen perusteella yhteen maakuntalakien, valinnanvapauslain ja tuottajalain esitykset, minkä vuoksi koko uudistuksen valmistelu pysähtyi valinnanvapauslain ongelmiin (Valli-Lintu 2019, 11, 40-41). Tämän seurauksena valinnanvapauslain käsittely ensin viivästyi ja lopulta pysähtyi, kun Sipilän hallitus jätti eronpyyntönsä 8. maaliskuuta 2019.

\section{JOHTOPÄÄTÖKSET}

Tämä tutkimus keskittyi analysoimaan tutkimustietoon perustuvan asiantuntijatiedon ja akatee- misten asiantuntijoiden roolia päätöksenteossa. Analyysin perusteella sote-uudistuksessa ei käytetty systemaattisesti hyväksi tutkimustietoa. Akateemisilla sote-asiantuntijoilla oli vähäinen rooli sote-uudistuksen valmistelussa ennen Sipilän hallitusta, joka ensimmäisenä sai vietyä eduskuntaan esityksen sote-uudistuksesta. Soteuudistuksen uskomusten perusteluissa korostui itsepäisyyden menetelmä aina Paras-hankkeesta Sipilän hallituksen ensimmäisten sote-lakiesitysten eduskuntaan saapumiseen asti. Useissa eri vaiheessa sote-valmistelua poliittiset linjaukset olivat ristiriidassa virkamies- ja akateemisten asiantuntijoiden näkemysten kanssa. Itsepäisyyden menetelmää voisi kuvata myös tutkimustiedon välttämiseksi päätöksenteossa tai politiikkaan perustuvaksi näytöksi (policy-based evidence) (Sorsa 2017; Marmot 2004).

Kataisen/Stubbin hallituksen kompuroinnin jälkeen julkisuudessa kaivattiin alinomaa asiantuntijoiden näkökulmaa sote-uudistukseen ja asiantuntijat pääsivät runsaasti esiin uudistuksen valmistelun aikana (Merikanto 2018a, 2018b). Monet asiantuntijat toivat toistuvasti esille, että vaikka heitä on kuultu heitä ei ole kuitenkaan kuunneltu. Sipilän hallituksen loppuvaiheessa uudistukseen kriittisesti suhtautuneilla sote-asiantuntijoilla oli kuitenkin tärkeä rooli uudistuksen kaatumisessa. Tällöin asiantuntijat turvautuivat lähes poikkeuksetta auktoriteetin menetelmään tieteellisen menetelmän sijasta. Asiantuntijuuteen kuuluva luottamuksen ja varmuuden tunne voi johtaa siihen, että asiantuntijat luottavat monimutkaisissa kysymyksissä tieteellisen menetelmän sijaan helpompia vastauksia tarjoavaan auktoriteetin menetelmään (Isopahkala-Bouret 2008). Auktoriteetin menetelmän vaarana on, että tieteellinen tieto ja asiantuntijuus kaventuvat politiikkaperusteisen evidenssin tuottamiseksi ja että tutkimustietoon perustuva asiantuntijuus hajaantuu monimutkaisissa kysymyksissä. Auktoriteetin menetelmän käyttö kertoo myös siitä, ettei akateemisten asiantuntijoiden osallistuminen vielä itsestään takaa tutkimustiedon käyttöä päätöksenteossa.

Saadut tulokset liittyvät Suomen sote-uudistuksen erityiseen kontekstiin, eivätkä ole sellaisenaan yleistettävissä tai siirrettävissä muihin konteksteihin. Niemisen ja kumppaneiden $(2019,93)$ laaja tutkimus tutkimustiedon käytöstä lainsäädäntöhankkeissa havaitsi suurim- 
maksi puutteeksi tutkimustiedon käytön pinnallisuuden, mikä voi liittyä edellä kuvattuun auktoriteetin menetelmän käyttöön.

Argumentaatioanalyysin avulla ei voida tutkia sitä, miten paljon tieto on tosiallisesti vaikuttanut tehtyihin ratkaisuihin. Analyysi kohdistuu vain siihen, millaisia argumentteja ratkaisuiden perusteluissa on käytetty. Edellä kuvattu analyysi ei vastaa myöskään siihen epäonnistuiko sote-uudistus siksi, ettei tutkimustietoa käytetty päätöksenteossa. Kuvatun analyysin tuloksia ja johtopäätöksiä tulkittaessa on otettava huomioon myös se, että olen toiminut edellä kuvatuista työryhmistä palvelurakennetyöryhmän, järjestämislakityöryhmän, parlamentaarisen valmistelun asiantuntujaryhmän sekä STM:n sote-asiantuntijaryhmän jäsenenä sekä kutsuttuna asiantuntijana kahdessa kuvatussa perustuslakivaliokunnan kuulemisessa.

Akateemisten asiantuntijoiden oma toiminta voi kuitenkin osin selittää sote-uudistuksen takeltelua. Brommelsin työryhmän osin tieteelliseen auktoriteettiin perustuva menetelmä ei johtanut valinnanvapausmalliin, joka olisi saanut muiden tieteellistä auktoriteettia edustaneiden asiantuntijoiden hyväksynnän. Kevälllä 2018 akateemiset sote-asiantuntijat olivat erimielisiä korjatun valinnanvapauslakiesityksen perustuslainmukaisuudesta. Samaan aikaan perustuslakiasiantuntijat olivat tiukoilla ja käytännölle vierailla tulkinnoillaan viemässä edellytykset uudistuksen toteuttamiselta (Valli-Lintu 2019, 47).

Ei ole myöskään selvää, olisiko sote-uudistus onnistunut vuosina 2015-2019, vaikka tieteellistä tietoa olisi käytetty enemmän uudistuksen valmistelussa. Myös tieteellisessä menetelmässä on rajoitteita. Tiede ei tuota yksiselitteistä vastausta sote-uudistuksen keskeisiin kysymyksiin. Ei ole esimerkiksi selvää, tulisiko julkisesti rahoitettujen palveluiden olla myös julkisesti tuotettuja. Palveluiden (erityisesti sosiaalipalveluiden) vaikuttavuudesta on kansainvälisesti erittäin niukasti tietoa. On myös otettava huomioon, ettei yhdessä maassa saatuja tuloksia voida - toisin kuin esimerkiksi sairauksien hoitoa koskevien Käypä hoito -suositusten valmistelussa - välttämättä sellaisenaan soveltaa toisessa maassa. Esimerkiksi useimmat tutkimukset kilpailusta terveydenhuoltomarkkinoilla on tehty Yhdysvalloissa (Pitkänen ja Pekola 2016), jonka järjestelmä on perin toisenlainen kuin Suomessa.

Lisäksi voi kysyä, voiko tieteellinen menetelmä ylipäätään luoda yhteisesti jaettua kumulatiivista tietoa ja yhteistä näkemystä sote-uudistuksesta. Edellä mainittujen tieteenalojen orientaatiot ovat hyvin erilaisia. Esimerkiksi terveystaloustiede on kiinnostunut siitä, miten rajallisten voimavarojen maailmassa voi kannustimien avulla saada mahdollisimman paljon terveyttä mahdollisimman tehokkaasti. Sosiaalityön kansainvälisessä määritelmässä tieteenalan tehtävänä on edistää sosiaalista yhteenkuuluvuutta sekä ihmisten ja yhteisöjen voimaantumista ja valtaistumista korostamalla yhteiskunnallisen oikeudenmukaisuuden, ihmisoikeuksien, kollektiivisen vastuun sekä moninaisuuden kunnioittamisen periaatteita.

Sote-uskomusten perustelua tieteellisellä menetelmällä horjuttaa myös se, että sote-uudistukseen liittyvät työryhmäraportit ja lakiesitykset ovat vain hyvin harvoissa kohdissa viitanneet vertaisarvioituihin tutkimuksiin. Samaan aikaan ongelmana on ollut se, etteivät sote-asiantuntijoiden lausunnot eduskunnan valiokunnissa ole olleet julkisia käsittelyn aikana eivätkä siten alttiita tieteelliselle kritiikille. Poikkeuksena on edellä mainittu asiantuntijaryhmän lausunto, joka julkaistiin Sosiaalilääketieteellisessä aikakauskirjassa (Lehtonen ym. 2018). Eduskunnan valiokunnille toimitetut lausunnot tulevat julkisiksi vasta valiokunnan mietinnön valmistumisen jälkeen. Toinen ongelma liittyy siihen, ettei asiantuntijoiden valinnassa ole kunnioitettu tieteellisen yhteisön autonomiaa, vaan ne ovat perustuneet poliittishallinnollisen tahon nimeämisvaltaan.

Sote-uudistusta on valmisteltu sadoissa eri ryhmissä. Niistä valtaosa on kuitenkin koostunut pääasiassa virkamiehistä, eikä niissä ole ollut muutamia poikkeuksia lukuun ottamatta mukana tutkijoita. Virkamiehet toimivat virkavastuulla, mutta ovat käytännössä sitoutuneet kulloinkin vallitseviin poliittisiin voimasuhteisiin. Poliitikkojen ja virkamiesten valtaa on korostanut se, että vaikka ministeriön asiantuntijaryhmissä on ollut eri tahoja - julkisia ja yksityisiä julkispalvelutuottajia, ammatti- ja muita etujärjestöjä, sektoritutkimuslaitoksia ja yliopistoja - eivät asiantuntijat kuitenkaan ole pääsääntöisesti olleet näiden tahojen nimeämiä. Valinnan 
on tehnyt ministeriö. Esimerkiksi Brommelsin valinnanvapausryhmän asiantuntijat oli selkeästi nimitetty poliittisin perustein. Sama pätee jossain määrin myös muihin asiantuntijaryhmiin.

Vaikka demokraattinen politiikka vaikuttaa kaoottiselta ja ajautuu usein umpikujiin, se kuitenkin oikeuttaa päätöksiä paremmin kuin teknokratia - pohjautuipa teknokratia kuinka hyvin näyttöön perustavaan tieteeseen tahansa. Julkisessa keskustelussa asiantuntijoiden mielipiteet helposti politisoituvat, jolloin sekä valmistelijoiden että päätöksentekijöiden on vaikea erottaa tieteelliseen auktoriteettiin perustuvaa mielipidettä vertaisarvioidun tutkimuksen tuottamasta johtopäätöksestä. Sote-uudistuksen valmistelu vuosina 2005-2019 kuvaa sitä, ettei tutkimuksen ja päätöksenteon yhteys ole suoraviivainen ja ettei akateemisten tutkijoiden ja poliittisten päätöksentekijöiden väliseen vuorovaikutukseen ole helppoa löytää toimivaa mallia. Politiikan, virkamiestyön ja tutkimustoiminnan instituutiot ja logiikat eivät ole kohdanneet uudistuksen valmistelussa tai ne ovat sotkeutuneet toisiinsa. Näin tapahtuu, kun asiantuntijat ovat politiikkavetoisia ja virkamiehet esiintyvät asiantuntijoina, ja kun yliopistoinstituution tutkimustoiminta ja asiantuntijuus hajaantuu useille yhteiskunnan sektoreille (vrt. Ahonen 2015).

Mikä neuvoksi? Ongelmaa voisi yrittää ratkaista korostamalla tieteellistä menetelmää paitsi systemaattisen tutkimuksen ja kirjallisuuskatsausten avulla myös konsensusraporteilla, joissa eri alojen asiantuntijat pyrkivät esittämään yhteisiä näkemyksiä. Menetelmä muistuttaa aikaisemmin Suomessa käytössä ollutta komitealaitosta. Uskomusten perusteleminen tieteellisellä tiedolla ei ole tutkijoiden etuoikeus eikä tieteellistä tietoa voi välttämättä soveltaa sote-uudistuksen kaltaiseen monimutkaiseen ilmiöön ilman kokemusta käytännöstä - on vaikea kuvitella Käypä hoito -suositusta sote-uudistuksen ongelmille. Käsite "käytännön yhteisöt" (communities of practice, $\mathrm{CoP}$ ) viittaa ryhmiin, joissa asiantuntemusta luonnehtivat yhteiset tavoitteet, toimintatavat ja kieli (Wenger 1998; Koivunen 2005). Käytännön yhteisöt luovat asiantuntijuutta sosiaalisen konstruktion avulla. Ryhmä kehittää ajattelu- ja toimintatapoja, joiden avulla se voi määritellä ja hankkia asiantuntemusta tietyltä alalta, joka voi olla professiota laajempi. Käytännön yhteisö tuo asiantuntemukseen kollektiivisen ulottuvuuden (Koivunen 2005). Käytännön yhteisö ei kuitenkaan edellytä tieteellisen menetelmän soveltamista. Tämän tyyppistä valmistelua edustavat edellä mainittu THL:n Jonottamatta hoitoon -aloite (Erhola ym. 2013) sekä STM:n asiantuntijaryhmän yhteinen lausunto vuonna 2017 (Lehtonen ym. 2018).

Käytännön yhteisöihin kuuluu se, että niiden jäsenillä on yhteinen kiinnostuksen aihe ja että niiden jäsenet pyrkivät yhdessä tavoitteellisesti hankkimaan tietoa kyseisestä aiheesta. Metodina voi olla esimerkiksi tiedon jakaminen ryhmissä, minkä avulla ryhmän jäsenet voivat oppia toisiltaan. Jos haettu tieto on avointa vertaisarvioitua tutkimustietoa, käytännön yhteisön voi tulkita soveltavan tieteellistä menetelmää. Niiden näkökulma voi olla kuitenkin laajempi ja sisältää paitsi akateemista tutkittua tietoa myös käytännön tietoa ja niin kutsuttua hiljaista tietoa. Akateemisten ja muiden soteasiantuntijoiden yhteinen, pitkäkestoinen ja tavoitteellinen työskentely käytännön yhteisön hengessä voisi tarjota ratkaisuja sote-uudistuksen umpikujiin.

Lopputuloksesta riippumatta sote-uudistuksen valmistelu vuosina 2005-2019 herättää pitkään kriittisiä kysymyksiä liittyen akateemisten asiantuntijoiden rooliin (ks. myös Erhola ym. 2019). Ovatko lausunnot olleet julkisuuskipeitä? Ovatko ne perustunet liian huteraan näyttöön ja liian vähäisiin omiin tieteellisiin julkaisuihin? Onko kannanottojen dokumentointi ollut riittävää? Samaan hengenvetoon on myös syytä pohtia, millaiset resurssit opetus-, tutkimus- ja hallinnollisen työn kuormittamilla akateemisilla asiantuntijoilla on ollut osallistua prosessiin. Yhteiskunnallinen vaikuttaminen vaati aikaa ja paneutumista, mitä akateeminen yhteisö ei riittävästi tunnista ja tunnusta.

Tutkimusta on rahoittanut Strategisen tutkimuksen neuvosto/312710 Kantola, Anu M. Kiitän kommenteista Lari Hokkasta, Juhani Lehtoa ja Esa Väliverrosta. 


\section{SEKUNDÄÄRIAINEISTO}

Brommels, Mats \& Aronkytö, Timo \& Kananoja, Aulikki \& Lillrank, Paul \& Reijula, Kari (2016). Valinnanvapaus ja monikanavarahoituksen $y k$ sinkertaistaminen sosiaali- ja terveydenhuollossa: Selvityshenkilöryhmän loppuraportti. Helsinki: Sosiaali- ja terveysministeriö.

Erhola, Marina \& Herrala, Jaakko \& Hiilamo, Heikki (2019). Syteen vai soteen asiantuntijoiden avulla. Yhteiskuntapolitiikka, 84(2), 226231

Erhola, Marina \& Jonsson, Pia Maria \& Pekurinen, Markku \& Teperi, Juha( 2013). Jonottamatta hoitoon. THL:n aloite perusterveydenhuollon vahvistamiseksi. Helsinki: Terveyden ja hyvinvoinnin laitos.

Erhola, Marina ym. (2014). SOTE-uudistuksen vaikutusten ennakkoarviointi. Helsinki: Terveyden ja hyvinvoinnin laitos.

Hiilamo, H. (2020). Why did Social and Healthcare Services Reform Fail in Finland? Socialmedicinsk Tidskrift 97(3),424-432.

Jonsson, Pia Maria (2017). Palveluiden järjestämisen nykytilanne Suomessa. THL:n sote-uudistuksen teemasivut.

https://hl.fi/fi/web/sote-uudistus/palvelujen-jarjestaminen/palvelujen-jarjestamisen-nykytilanne-suomessa viitattu 14.8.2018.

Lehtonen, Lasse ym. (2018). Valinnanvapaus SOTEuudistuksessa. Sosiaalilääketieteellinen aikakausilehti 55(1), 78-87.

Manssila, Sonja \& Mattson, Lotta (toim.) (2019). Maakunta- ja sote-uudistuksen loppuraportti. Kokemuksia valmistelutyöstä, oppeja sekä johtopäätöksiä. Valtiovarainministeriön julkaisuja,40 Helsinki: Valtiovarainministeriö.

Sipilä, Juha (2015). Ratkaisujen Suomi. Pääministeri Juha Sipilän hallituksen strateginen ohjelma 29.5.2015, Helsinki: Valtioneuvoston kanslia.

STM (2011). Sosiaali- ja terveydenhuollon järjestämistä, kehittämistä ja valvontaa koskevan lainsäädännön uudistaminen. Peruslinjauksia valmistelevan työryhmän loppuraportti. Sosiaalija terveysministeriön raportteja ja muistiota, 7 . Helsinki: Sosiaali- ja terveysministeriö.

STM (2012a). Palvelurakennetyöryhmän väliraportti. Sosiaali- ja terveysministeriön raportteja ja muistiota, 17. Helsinki: Sosiaali- ja terveysministeriö.

STM (2012b). Palvelurakennetyöryhmän loppuraportti. Sosiaali- ja terveysministeriön raportteja ja muistiota, 30. Helsinki: Sosiaali- ja terveysministeriö.
STM (2013). Sosiaali- ja terveydenhuollon järjestämislain valmisteluryhmän loppuraportti. Sosiaali- ja terveysministeriön raportteja ja muistioita, 45. Helsinki: Sosiaali- ja terveysministeriö.

STM (2015a) Sosiaali- ja terveydenhuollon uudistuksen ja itsehallintoalueiden perustamisen sekä aluehallintouudistuksen valmistelu - Selvityshenkilöhanke. Helsinki: Sosiaali- ja terveysministeriö.

STM (2015b). Virkamiesselvitys: uusien itsehallintoalueiden muodostaminen. https://stm.fi/documents/1271139/1860522/Aluejakomuistio_ final_0511.pdf/8cabc755-d384-44f5-9baec0231f25e2a7/Aluejakomuistio_final_0511.pdf. pdf viitattu 14.6.2018.

THL:n asiantuntijaryhmä (2011). Sosiaali- ja terveydenhuollon monikanavaisen rahoituksen edut, haitat ja kehittämistarpeet. Helsinki: Terveyden ja hyvinvoinnin laitos.

THL:n asiantuntijaryhmä (2012). Sosiaali- ja terveydenhuollon rahoituksen kehittäminen: Kohti yksikanavaista alueellista järjestäjä-rahoittajaa. Helsinki: Terveyden ja hyvinvoinnin laitos.

THL (2013). SOTE-uudistuksen vaikutusten alustava arviointi. Helsinki: Terveyden ja hyvinvoinnin laitos.

Valli-Lintu, Auli (2017). Sote- ja kuntarakenteen pitkä kujanjuoksu. Helsinki: Kunnallisalan kehittämissäätiö.

Valli-Lintu, Auli (2019). Sote- ja kuntarakenteen pitkä kujanjuoksu - osa II. Helsinki: Kunnallisalan kehittämissäätiö.

Valtiovarainministeriö (2009). Valtioneuvoston selonteko kunta- ja palvelurakenneuudistuksesta. Helsinki: Valtiovarainministeriö.

Välimäki, Kari (2013) Kakkua jaettavaksi. Helsinki: Kunnaisalan kehittämissäätiö.

\section{LÄHTEET}

Abbot, Andrew (1988). The System of Professions. Chicago: Chicago University Press.

Ahonen, Pertti (2015). Asiantuntijatiedon merkitys hallinnon ja politiikan kentillä: politiikan, virkamiesten ja tieteen vuorovaikutuksen tiedonpolitologiaa. Teoksessa Virtanen, Petri, Stenvall, Jari \& Rannisto, Pasi-Heikki (toim.) Tiedolla johtaminen hallinnossa. Teoriaa ja käytäntöjä. (s. 150-171). Tampere: Tampere University Press.

Ansell, Christian \& Geyer, Robert (2017). Pragmatic Complexity a new foundation for 
moving beyond evidence-based policy-making? Policy Studies 38(2), 149-167. https://doi.org/10.1080/01442872.2016.1219033

Baron, Jon (2018) A Brief History of EvidenceBased Policy. The Annals of the American Acedemy 678(1), 40-50. https://doi.org/10.1177\%2F0002716218763128

Collins, Harry \& Evans, Robert (2007). Rethinking expertise. Chicago: Chicago University Press.

Hellström, Eeva \& Ikäheimo, Hannu Pekka \& Hakapää, Jyrki\& Lehtomäki, Joona \& Saari, Milja (2019). Tiedonkäytön tulevaisuus yhteiskunnallisessa päätöksenteossa. Työpaperi. Helsinki: Sitra.

Hukkinen, Janne (2016). A model of the temporal dynamics of knowledge brokerage in sustainable development. Evidence \& Policy 12(3):321-340. https://doi.org/10.1332/17442 6416X14712607933264

Isopahkala-Bouret, Ulpukka (2008). Asiantuntijuus kokemuksena. Aikuiskasvatus, 28(2), 84-93.

Keisarillisen majesteetin armollinen asetus kunnallishallituksesta maalla (1865), annettu Helsingissä 6 päivänä helmikuuta 1865 .

Keisarillisen majesteetin armollinen julistus muutoksesta niistä tätä ennen annetuista säännöistä, jotka koskevat kustannuksia kuntien yksityisestä sairashoidosta (1869), annettu Helsingissä 13 päivänä huhtikuuta 1869.

Koivunen, Niina (2005). Miten kollektiivinen asiantuntijuus organisoituu? Hallinnon tutkimus 24 (3), 32-45.

Lammintakanen, Johanna \& Saarti, Jarmo \& Vuori Jari (2018). Tutkimustiedolla vaikuttaminen jälkidigitaalisessa maailmassa - akateeminen asiantuntijatyö yhteiskunnallisena tehtävänäTeoksesssa Lammintakanen, Johanna \& Laulainen Sanna (toim.), Kohti vaikuttavaa päätöksentekoa ja johtamista hyvinvointipalveluissa (s. 211-227). Kuopio: University of Eastern Finland.

Lähteenmäki-Smith, Kaisa \& Kuitunen, Soile (2015). Näyttöperusteisuus päätöksenteossa: tiede- ja tutkimusperusteisuudesta tekemisen demokratiaan? Teoksessa Virtanen, Petri, Stenvall Jari Stenvall \& Rannisto, Pasi-Heikki (toim.), Tiedolla johtaminen hallinnossa. Teoriaa ja käytäntöjä. (s. 115-149). Tampere: Tampere University Press.

Marmot, Michael (2004). Evidence based policy or policy based evidence? British Medical Journal 328(7445):906-7.

https://doi.org/10.1136/bmj.328.7445.906

Mattila, Yrjö (2011). Suuria käännekohtia vai tasaista kehitystä? Tutkimus Suomen terveydenhuollon suuntaviivoista. Helsinki: Kela.
Merikanto, Tiina (2018a). Analyysi: "Taivas tipahtaa päällemme, jos sote kaatuu" - ei kyllä tipahda. Blogi-kirjoitus Ylen sivuilla 29.5.2018. https://yle.fi/uutiset/3-10226563 viitattu 14.6.2018.

Merikanto, Tiina (2018b). Professorit: ihmisten pompottelu ja kustannukset eivät vähene ilman korjauksia - sote-paketin puuttuva osa tulossa kansanedustajien pöydille. Blogi-kirjoitus ylen sivuilla 7.3.2018.

https://yle.fi/uutiset/3-10093028 viitattu 14.6.2018.

Michaels, Sarah (2009). Matching knowledge brokering strategies to environmental policy problems and settings. Environmental Science and Policy 12:994-1011.

https://doi.org/10.1016/j.envsci.2009.05.002

Muuri, Anu (2016). Kansainväliset kokemukset sosiaali- ja terveydenhuollon ohjausjärjestelmistä: Sosiaalihuolto. Teoksessa Keskimäki, Ilmo \& Moisio, Antti \& Pekurinen, Markku (toim.) Julkisen talouden ohjaus ja sosiaali- ja terveydenhuollon ja koulutuksen rakenneuudistus.

(s. 58-65). Helsinki: Valtioneuvoston selvitysja tutkimustoiminnan julkaisusarja 22.

Nieminen, Kati \& Alasuutari, Noora \& Kautto, Petrus \& Saarela, Sanna-Riikka \& Järvikangas, Inka \& Hiltunen, Elina \& Rantala, Kati (2019). Tutkimustiedon hyödyntämisen hyvät käytännöt lainvalmistelussa: kohti parempaa sääntelyä? Helsinki: Valtioneuvoston selvitys- ja tutkimustoiminnan julkaisusarja, 38 .

Palukka, Hannele \& Auvinen, Petra \& Tiilikka, Tiina (2017). Alkon toimija-asemat Alkoholipolitiikka- ja Yhteiskuntapolitiikka-lehtien pääkirjoituksissa 1970-2012. Yhteiskuntapolitiikka 82(2), 176-187.

Pekurinen, Markku \& Erhola, Marina \& Häkkinen, Unto \& Jonsson, Pia Maria \& Keskimäki, Ilmo \& Kokko, Simo \& Kärkkäinen, Jukka \& Widström, Eeva \& Vuorenkoski, Lauri (2011). Sosiaali- ja terveydenhuollon monikanavaisen rahoituksen edut, haitat ja kehittämistarpeet. Helsinki: Terveyden ja hyvinvoinnin laitos.

Peirce, Charles (1877). The Fixation of Belief. Popular Science Monthly 12, 1-15.

Pitkänen, Visa \& Pekola, Piia (2016). Valinnanvapaus ja kilpailu terveyspalveluissa. Työpapereita 86. Helsinki: Kela.

Rose, David \& Mukherjee, Nibedita \& Simmons, Benno \& Tew, Eleanor \& Robertson, Rebecca \& Vadrot, Alice \& Doubleday, Robert \& Sutherland, William ( 2017). Policy windows for the environment: Tips for improving the uptake of scientific knowledge. Environmental Science \& Policy. https://doi.org/10.1016/j.envsci.2017.07.013 
Sorsa, Ville-Pekka (2017). Pääkirjoitus: Millaista tutkimustietoa päätöksentekoon. Poliittinen talous 5(1), 75-89.

Uimonen Risto (2015). Juha Sipilä. Keskustajohtajan henkilökuva. Helsinki: Minerva.

Virtanen, Petri \& Stenvall, Jari \& Rannisto, PasiHeikki (2015). Julkiseen politiikkaan liittyvä oppiminen ja tietoon perustuva päätöksenteko. Teoksessa Virtanen, Petri, Stenvall, Jari \& Rannisto, Pasi-Heikki (toim.), Tiedolla johtaminen hallinnossa. Teoriaa ja käytäntöjä. Tampere: Tampere University Press.

Väliverronen, Esa (2016). Julkinen tiede. Tampere: Vastapaino.

Waris, Olli (2018). IL kysyi sote-asiantuntijaryhmältä, pitäisikö hallituksen malli viedä nyt maa- liin: Kyllä-äänet voittivat 9-5. Iltalehti, 14.3.2018

https://www.iltalehti.fi/politiik-

$\mathrm{ka} / 201803142200810215$ _pi.shtml (viitattu 5.6.2020).

Wenger, Etienne (1998). Communities of practice: Learning, meaning, and identity. Cambridge: Cambridge University Press.

Ylönen, Matti \& Jaakkola, Jussi \& Saari, Leevi \& Hiilamo, Heikki (2020). Näyttöperusteisuus ja yritysten verotus: ekonomismin nousu suomalaisen yhteisöveropolitiikan tiedontuotannossa. Poliittinen talous, 8(1). Noudettu osoitteesta https://journal.fi/poliittinentalous/article/ view/96159 